\title{
Synaptic loss in schizophrenia: a meta-analysis and systematic review of synaptic protein and mRNA measures
}

\author{
Emanuele Felice Osimo $\mathbb{D}^{1,2,3,4} \cdot$ Katherine Beck ${ }^{1,2,5,6} \cdot$ Tiago Reis Marques ${ }^{1,2,5,6} \cdot$ Oliver D Howes ${ }^{1,2,5,6}$
}

Received: 1 November 2017 / Revised: 5 January 2018 / Accepted: 31 January 2018 / Published online: 6 March 2018

(c) The Author(s) 2018. This article is published with open access

\begin{abstract}
Although synaptic loss is thought to be core to the pathophysiology of schizophrenia, the nature, consistency and magnitude of synaptic protein and mRNA changes has not been systematically appraised. Our objective was thus to systematically review and meta-analyse findings. The entire PubMed database was searched for studies from inception date to the 1st of July 2017. We selected case-control postmortem studies in schizophrenia quantifying synaptic protein or mRNA levels in brain tissue. The difference in protein and mRNA levels between cases and controls was extracted and meta-analysis conducted. Among the results, we found a significant reduction in synaptophysin in schizophrenia in the hippocampus (effect size: $-0.65, p<0.01$ ), frontal (effect size: $-0.36, p=0.04$ ), and cingulate cortices (effect size: $-0.54, p=0.02$ ), but no significant changes for synaptophysin in occipital and temporal cortices, and no changes for SNAP-25, PSD-95, VAMP, and syntaxin in frontal cortex. There were insufficient studies for meta-analysis of complexins, synapsins, rab3A and synaptotagmin and mRNA measures. Findings are summarised for these, which generally show reductions in SNAP-25, PSD-95, synapsin and rab3A protein levels in the hippocampus but inconsistency in other regions. Our findings of moderate-large reductions in synaptophysin in hippocampus and frontal cortical regions, and a tendency for reductions in other pre- and postsynaptic proteins in the hippocampus are consistent with models that implicate synaptic loss in schizophrenia. However, they also identify potential differences between regions and proteins, suggesting synaptic loss is not uniform in nature or extent.
\end{abstract}

Electronic supplementary material The online version of this article (https://doi.org/10.1038/s41380-018-0041-5) contains supplementary material, which is available to authorised users.

$\checkmark$ Oliver D Howes

oliver.howes@kcl.ac.uk

1 Psychiatric Imaging Group, MRC London Institute of Medical Sciences, Hammersmith Hospital, Imperial College London, London, UK

2 Psychiatric Imaging Group, Institute of Clinical Sciences, Faculty of Medicine, Imperial College London, London, UK

3 Department of Psychiatry, University of Cambridge, Cambridge, UK

4 Cambridgeshire and Peterborough NHS Foundation Trust, Cambridge, UK

5 Department of Psychosis Studies, Institute of Psychiatry, Psychology and Neuroscience, King's College London, London, UK

6 South London and Maudsley NHS Foundation Trust, Camberwell, London, UK

\section{Introduction}

Schizophrenia is a chronic mental illness, affecting $~ 1 \%$ of the population $[1,2]$. Imaging studies have demonstrated that schizophrenia is associated with ventricular enlargement $[3,4]$, a whole brain volume reduction of around $3 \%$, and regional volume reductions of $6-10 \%$ in grey matter areas such as the frontal cortex [5, 6] and hippocampus [710], as well as alterations in astroglial markers [11, 12]. However, histopathological work has failed to find clear evidence of gliosis or other degenerative changes in schizophrenia, and, while there is cortical volume loss, this occurs in the absence of neuronal cell loss [13-18]. Instead, it has been suggested that lower grey matter volumes are due to a reduction in synaptic levels, which would be compatible with the neurodevelopmental hypothesis of schizophrenia [2, 19-22].

A number of proteins expressed in presynaptic terminals and the postsynaptic density (Fig. 1) are used as markers of synaptic density [23-26]. Synaptophysin is the most studied presynaptic protein, and an accurate index of neuronal synaptic 


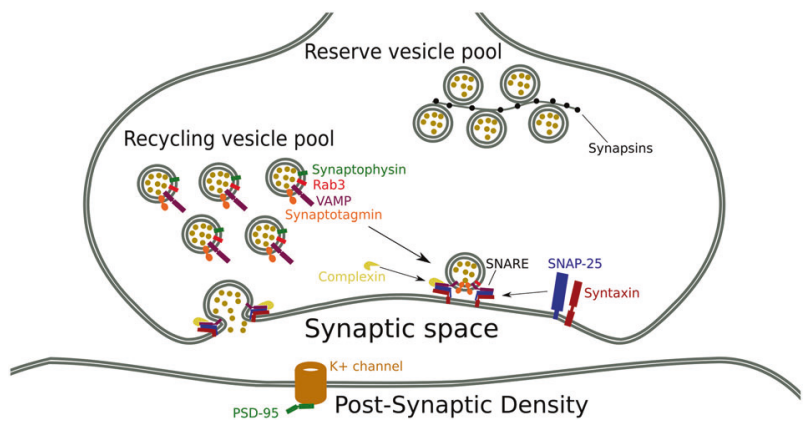

Fig. 1 Showing the location of synaptic proteins in the synapses. Rab3 Ras-related protein, VAMP vesicle-associated membrane protein, also known as synaptobrevin, SNAP-25 synaptosomal-associated protein 25 , PSD-95 postsynaptic density protein 95, SNARE SNap REceptor complex

density [27] because it is limited to neuronal synapses [24]. This protein interacts with synaptobrevin, thus participating in synaptic vesicle exocytosis [28]. It is specifically enriched in presynaptic nerve terminals, and is integral to the synaptic vesicle membrane [29, 30]. Consequently, it has been widely used in the quantification of synapses in human postmortem cortical samples $[24,25]$. Other synaptic markers include the SNap Receptor (SNARE) complex proteins, comprising SNAP-25 (Synaptosomal-associated protein 25), syntaxin and vesicle-associated membrane protein (VAMP), also known as Synaptobrevin. The SNARE complex is crucial for calciumdependent exocytosis at chemical synapses and is required for dopaminergic, serotonergic [31] and glutamatergic function [32]. Given the potential role of these systems in schizophrenia $[33,34]$, this makes the SNARE complex of particular interest. Synaptophysin and SNARE complex proteins are depleted in conditions associated with synaptic loss, such as Alzheimer's disease, other dementias and epilepsy [35-37]. Complexins are presynaptic membrane proteins that bind syntaxin, and are thought to be SNARE modulators. Complexin I is enriched in inhibitory neurons, while Complexin II is more commonly found in excitatory neurons [38, 39]. Synapsin I and II are proteins involved in neurite elongation and synapse formation and maintenance [40]; synapsin III is also a modulator of plasticity processes and of dopaminergic function [41]. Rab3A (Ras-related protein Rab-3A) and synaptotagmin are both involved in regulating synaptic vesicle exocytosis [42, 43]. PSD-95 (postsynaptic density protein 95) is abundant in the brain and concentrated in the postsynaptic density (PSD). It has been implicated in forming and maintaining excitatory synapses [44, 45], and in regulating synaptic strength and plasticity by interacting with other synaptic proteins, including glutamate receptors [46].

To our knowledge, there has not been a previous metaanalysis of synaptic protein levels in schizophrenia. We therefore aimed to synthesise the postmortem findings in patients with schizophrenia and healthy controls, and then discuss the implications of these findings in relation to the pathophysiology of the disorder.

\section{Methods and materials}

\section{Data extraction}

The main outcome measure was the difference in synaptic protein and mRNA levels between patients with schizophrenia and healthy controls. In addition, we extracted the following variables: sample size, methods of quantification, inclusion criteria, mean age, patients' medication, postmortem interval (PMI), cause of death, percentage of suicides, and whether the analysis was blind to group status.

\section{Statistical analysis}

We performed a meta-analysis when there were at least 5 independent data sets in each specific brain region, as recommended for meta-analyses using random-effects approaches [47].

The main outcome measure was the effect size (ES) (Hedges' $g$ ) of synaptic protein/mRNA change in patients with schizophrenia and healthy controls for each reported region or sub-region of interest. See Supplementary Information for further methodological details.

\section{Results}

The literature search yielded 281 results, from which we identified 60 relevant papers (see Supplementary Figure 1 for the PRISMA diagram of the literature search). 36 of the 60 studies met criteria for inclusion in the quantitative synthesis. We were able to perform a meta-analysis of synaptophysin protein levels for hippocampus, frontal cortex, cingulate cortex (CC), temporal cortex and occipital cortex. In the frontal cortex, it was possible to perform a meta-analysis of the following synaptic proteins: synaptophysin, SNAP-25, PSD-95, VAMP, and syntaxin. All studies included in the meta-analyses-matched cases and controls for age at death except for one [48], and postmortem interval (PMI) was matched in 31 out of 36 studies. 19 out of the 36 studies $(52.8 \%)$ reported that the experimenter was blind to diagnosis while conducting their analyses. See supplementary Tables 1-9 for these and further details of the studies [48-107].

There were insufficient data for meta-analysis of mRNA data in any brain region. Instead the results from the individual studies of mRNA and protein levels, where there were insufficient studies for meta-analysis are summarised below and in Supplementary Tables 1-9. 


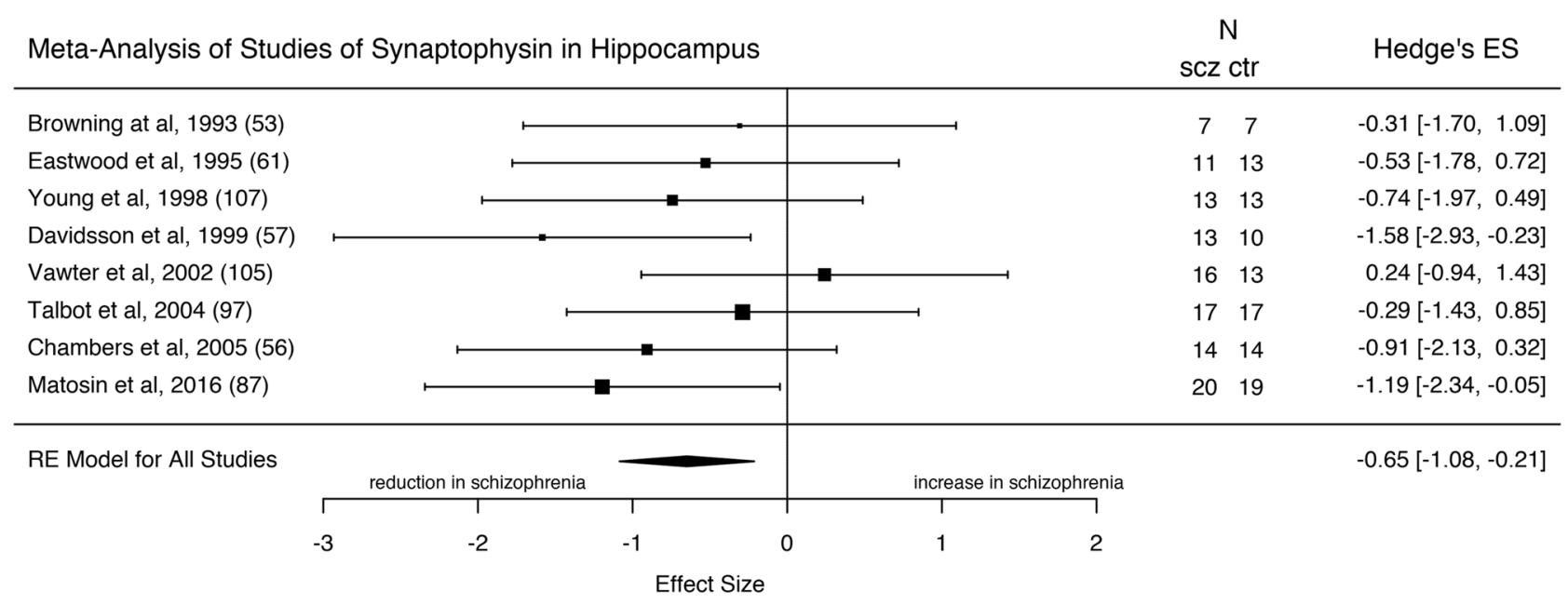

Fig. 2 Forest plot showing the effect sizes for studies of synaptophysin in hippocampus in schizophrenia patients as compared to controls. There was a significant reduction in schizophrenia (effect size $=-0.65, p=0.0036$ )

\section{Synaptophysin levels in the hippocampus}

Eight studies (111 patients with schizophrenia and 106 healthy controls) measured synaptophysin levels in the hippocampus (CA1-4 and Dentate Gyrus). Synaptophysin was significantly reduced in patients with schizophrenia with an ES of -0.65 (Fig. 2; $z=-2.91 ; 95 \%$ confidence interval $(\mathrm{CI})=-1.08,-0.21 ; p=0.0036)$. The $I^{2}$ statistic revealed low heterogeneity $\left(I^{2}=0 \% ; 95 \% \mathrm{CI}=0,70.5\right.$; Cochrane's $Q=5.7 ; p=0.57)$. The funnel plot appeared symmetrical, and a regression test for funnel plot asymmetry was non-significant $(z=-0.54 ; p=0.59)$, suggesting there is no evidence of publication bias (Supplementary Figure 2). The studies were well matched for PMI and the meta-regression for the proportion of suicides was not significant $(p=0.83$, for the studies where suicide data were available), suggesting this was not a major bias. Of the two mRNA studies of synaptophysin in the hippocampus, one showed significantly decreased synaptophysin mRNA levels in schizophrenia, the other a non-significant reduction $[59,106]$ (see Supplementary Table 1).

\section{Summary of findings with other synaptic proteins and mRNAs}

In the hippocampus, three studies examined SNAP-25 protein levels, two of which found a significant reduction in schizophrenia. Three studies measured PSD-95 protein levels, one of which found a significant reduction, the other found a trend reduction in schizophrenia. For the complexins, two studies measured protein levels and found no change, and two studies measured mRNA levels separately for complexin I (which was only reduced in some subfields) and complexin II (which was significantly reduced overall in one study, and in some subfields in the other). Four studies measured synapsin protein levels, three of which found a significant reduction in schizophrenia. Rab3A protein levels were studied twice and both times were found significantly reduced in schizophrenia.

\section{Synaptic proteins and mRNA levels in frontal cortex}

\section{Synaptophysin}

Thirteen studies comprising 170 patients with schizophrenia and 169 healthy controls measured synaptophysin levels in frontal cortical regions (approximating Brodmann Areas 9, 10, 46, 47) (Fig. 3). The majority of studies of the frontal cortex examined the dorso-lateral pre-frontal cortex (DLPFC; approximating BAs 9 and 46) [57, 60, 69, 70, 73, 74, 76, 89, 95], while three studies examined BAs 10 and 45 [79, 83, 92]. Synaptophysin was significantly reduced in patients with schizophrenia with an ES of $-0.36(z=-2.05 ; 95 \% \mathrm{CI}=$ $-0.70,-0.02 ; p=0.04)$. The $I^{2}$ statistic revealed low heterogeneity $\left(I^{2}=0 \%\right.$; $95 \% \mathrm{CI}=0-50.1 \%$; Cochrane's $Q=8.1 ; p$ $=0.78$ ). Inspection of the funnel plot did not reveal asymmetry (Supplementary Figure 3), and the regression test for funnel plot asymmetry was non-significant $(z=-1.15 ; p=0.25)$. A sub-analysis only including studies relating to the DLPFC was non-significant $(\mathrm{ES}=-0.23 ; z=-1.14 ; p=0.25)$, while the number of studies investigating other frontal areas was not sufficient for a separate sub-analysis. An exploratory metaregression of the effect of the percentage of suicides on the ES for the studies where this information was available showed no significant effect $(p=0.98)$. PMI was significantly different between cases and controls in one study [69]. In case this was biasing the results, we excluded this study and re-ran the metaanalysis, finding the reduction in synaptophysin levels 


\section{Meta-Analysis of Studies of Synaptophysin in Frontal Cortex}

$\mathrm{N}$ Scz ctr

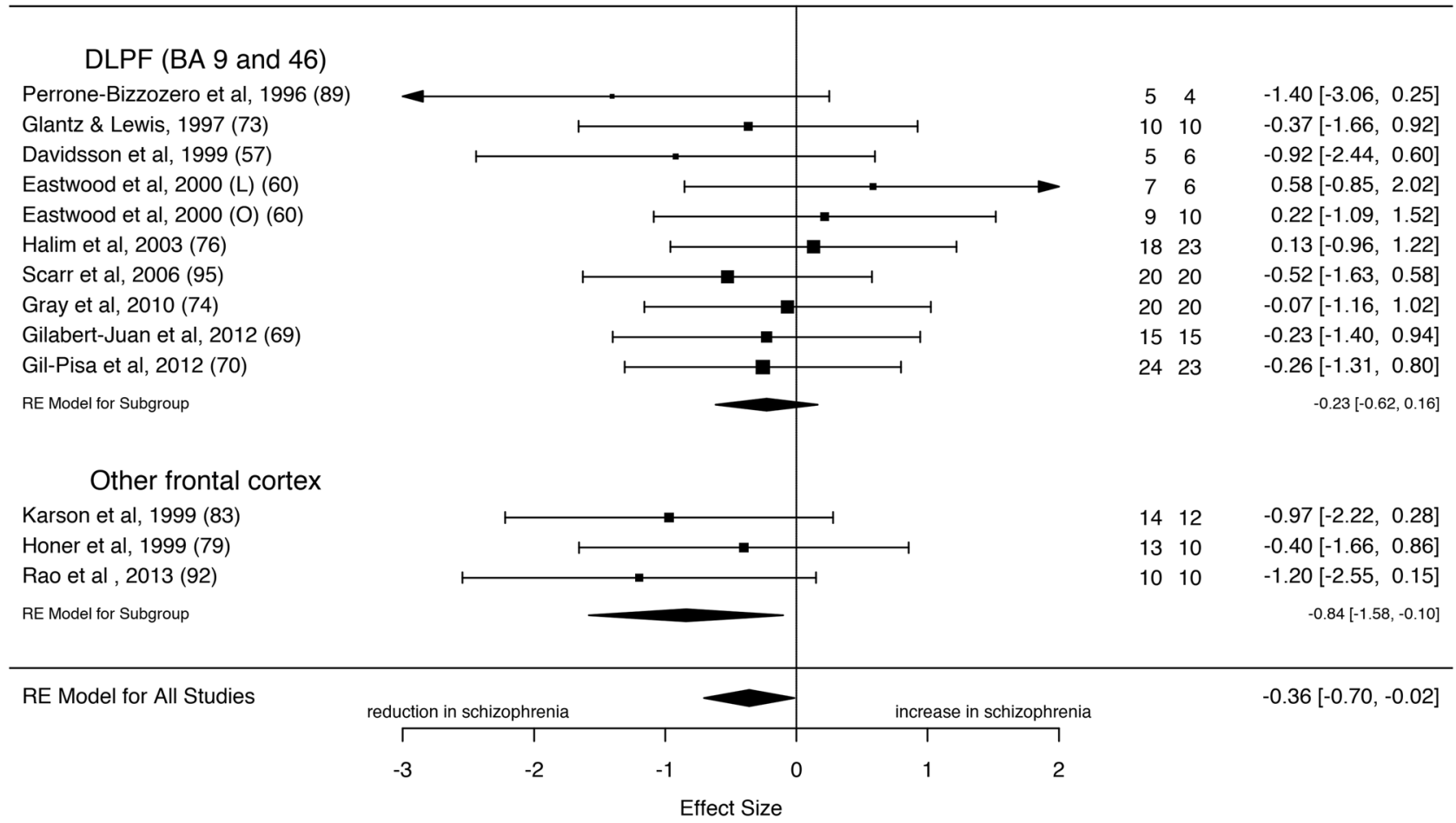

Fig. 3 Forest plot showing the effect sizes for studies of synaptophysin in frontal cortex in schizophrenia patients as compared to controls. There was a significant reduction in schizophrenia (effect size $=-0.36, p=0.04$ )

remained significant $(\mathrm{ES}=-0.37 ; z=-2.03 ; p=0.04)$. With regards to mRNA data for synaptophysin in the frontal cortex, one study reports a significant reduction in schizophrenia, while one reports a significant reduction in BAs 17 and 22 and a nonsignificant reduction in BAs 9 and 46, and two studies suggest no change in frontal cortex (Supplementary Table 1).

\section{SNAP-25}

Nine studies comprising 139 patients with schizophrenia and 138 controls measured SNAP-25 levels in frontal cortex (approximating BAs 9, 10, 46, 47) (Fig. 4). The overall results indicate no significant change in SNAP-25 in frontal cortex in schizophrenia (ES: $-0.18 ; z=-0.90 ; 95 \% \mathrm{CI}=-0.58,0.21$; $p=0.37)$. The $I^{2}$ statistic revealed low heterogeneity $\left(I^{2}=0 \%\right.$; 95\% CI $=0-81 \%$; Cochrane's $Q=9.5 ; p=0.30$ ). The three mRNA studies of SNAP-25 in the frontal cortex showed nonsignificant reductions or no changes in mRNA levels in schizophrenia (Supplementary Table 2).

\section{PSD-95, VAMP, and syntaxin}

PSD-95 (6 studies, ES $=-0.34, p=0.14$ ), VAMP (6 studies, $\mathrm{ES}=-0.26, p=0.27$ ), and syntaxin (6 studies, $\mathrm{ES}=$
$0.16, p=0.52)$ protein levels did not differ in frontal cortex between schizophrenia patients and controls (Supplementary Figures 4-6). Of the four mRNA studies of PSD-95 in the frontal cortex, two showed no change, one a nonsignificant reduction and one non-significant increase in mRNA levels in schizophrenia (Supplementary Table 3). One study measured VAMP mRNA levels and found no difference in frontal cortex (Supplementary Table 5). Our search did not identify any studies of syntaxin mRNA in frontal cortex.

\section{Summary of findings with other synaptic proteins and mRNAs}

For frontal cortex, four studies measured levels of the complexins: one of the two studies looking at protein levels found a significant reduction in complexin I in schizophrenia, and one of the studies looking at mRNA levels found a reduction in complexin II. Three studies measured synapsin protein levels, and one found a significant reduction in synapsin III, while of the two studies quantifying mRNA, one found a significant reduction in synapsin II in schizophrenia. Both studies of Rab3A found a significant reduction in protein levels in frontal cortex. No change was 


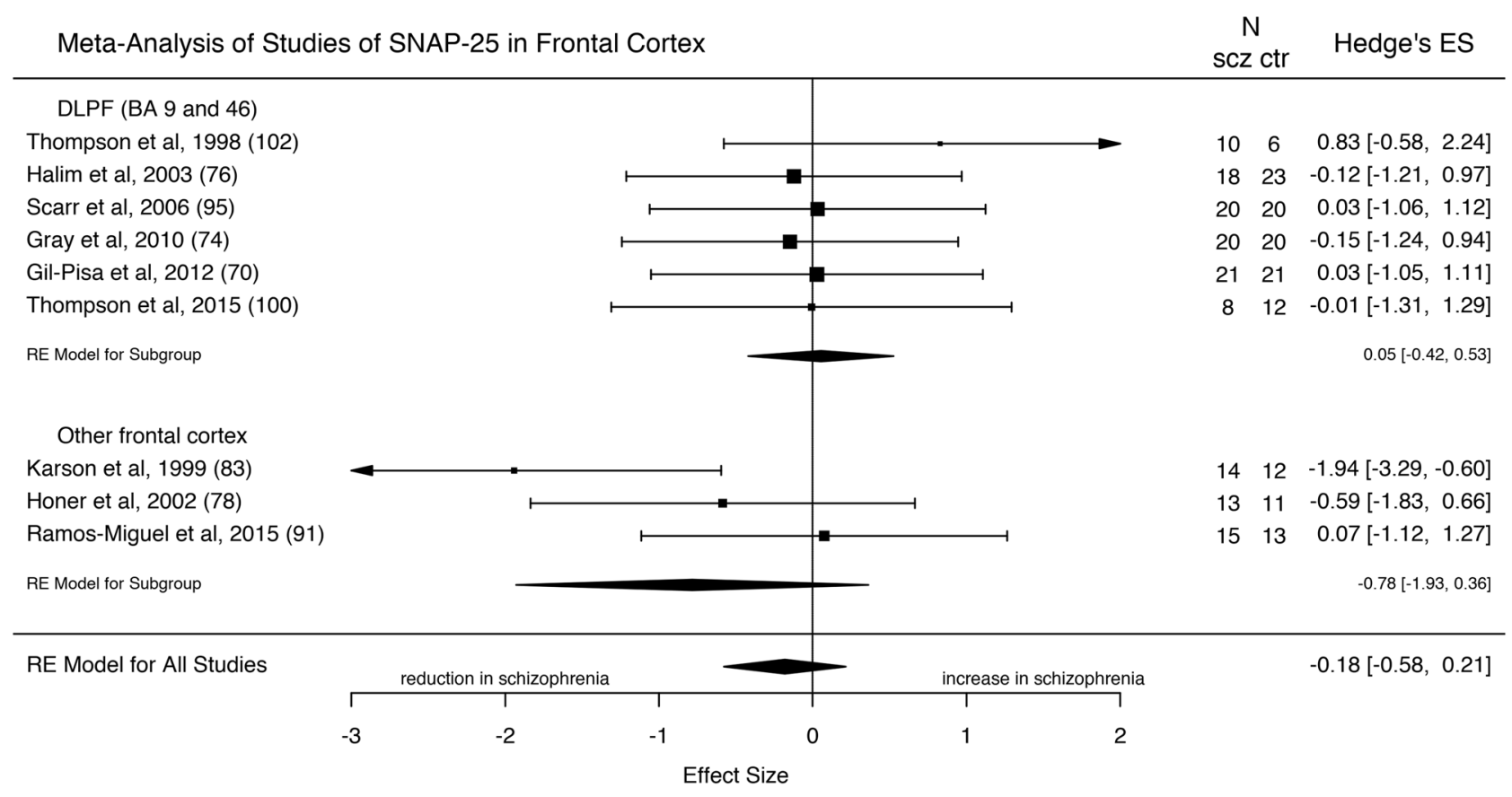

Fig. 4 Forest plot showing the effect sizes for studies of SNAP-25 in frontal cortex in schizophrenia patients as compared to controls. There was no significant reduction in schizophrenia (effect size $=-0.18, p=0.37$ )

found in protein levels in schizophrenia in two studies for synaptotagmin in this region.

\section{Synaptophysin levels in cingulate cortex}

Seven studies (comprising 115 patients with schizophrenia and 105 healthy controls) measured synaptophysin in the CC (approximating BAs 24, 32, 33). Synaptophysin was significantly reduced in the $\mathrm{CC}$ of patients with schizophrenia with an ES of -0.54 (Fig. $5 ; z=-2.35 ; 95 \%$ CI $=-0.99,-0.09 ; p=0.02)$. The $I^{2}$ statistic revealed low heterogeneity $\left(I^{2}=0 \%\right.$; CI $=0,80.4$; Cochrane's $Q=6.0$; $p=0.42$ ). Inspection of the funnel plot suggested a degree of asymmetry, however, the regression test for funnel plot asymmetry was non-significant $(z=-1.78 ; p=0.07)$ (Supplementary Figure 7), and the trim and fill analysis did not reveal any missing studies. There was insufficient information to test the effect of suicide as a metaregressor. While the majority of studies reported samples coming from the anterior CC (ACC), Honer et al. [80] describe their sample as from the $\mathrm{CC}$ without specifying a particular sub-region. A sub-analysis removing this study shows that there still is a significant reduction in synaptophysin levels in the ACC in schizophrenia relative to controls $\quad(\mathrm{ES}=-0.61 ; \quad z=-2.27 ; \quad 95 \% \quad \mathrm{CI}=-1.14$, $-0.08 ; p=0.02$ ). In further sensitivity analyses, removing the study by Landén et al. [86], which shows a significant difference in PMI between cases and controls, affects the overall significance $(\mathrm{ES}=-0.42 ; z=-1.73 ; \mathrm{CI}=-0.90$, $0.06 ; p=0.08$ ). Our search did not find a study of synaptophysin mRNA in this region.

\section{Summary of findings with other synaptic proteins and $\mathrm{mRNAs}$ in cingulate cortex}

Two studies measured SNAP-25 protein levels in the CC, and found no significant change. With regards to PSD-95, three studies measured protein levels in CC: two found a significant reduction, the other no change in schizophrenia, while one study found a significant increase in PSD-95 mRNA in this area. One study measured the complexins in this area and found no change. Both studies of Rab3A found a significant reduction in protein levels in $\mathrm{CC}$ in schizophrenia.

\section{Synaptophysin levels in temporal cortex}

Six series in five studies (60 patients and 57 controls) measured synaptophysin protein levels in the temporal cortex. There were no significant differences in synaptophysin levels in schizophrenia patients when compared to healthy controls in the temporal cortex $(\mathrm{ES}=-0.31 ; z=$ $-1.12 ; 95 \% \mathrm{CI}=-0.85,0.23 ; p=0.26$-Supplementary Figure 8 ). Synaptophysin mRNA were found significantly decreased in two of three studies of this molecule in temporal cortex. 


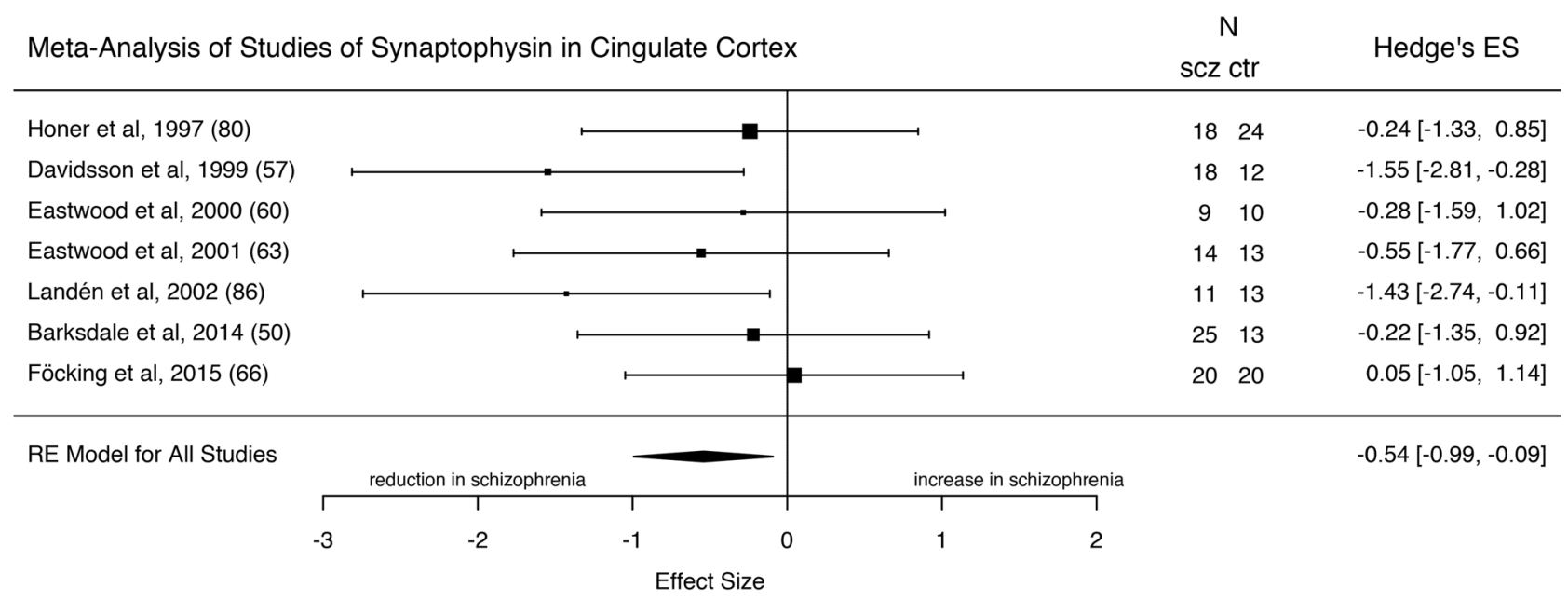

Fig. 5 Forest plot showing the effect sizes for synaptophysin levels in the cingulate cortex in schizophrenia patients as compared to controls. There was a significant reduction in schizophrenia (effect size $=-0.54, p=0.02$ )

\section{Summary of findings with other synaptic proteins and mRNA levels in temporal cortex}

SNAP-25 protein levels were found significantly decreased in one of two studies, while mRNA levels were unchanged in one study in schizophrenia. Syntaxin, VAMP, synapsin, Rab3A, and synaptotagmin mRNA levels were not significantly altered in one study each. Rab3A protein levels were unchanged in two studies in temporal cortex. For the complexins, one study analysed protein levels and found a reduction in complexin II only. For complexin mRNAs, three studies reported reductions in complexin II, while no study found significant reductions in complexin I.

\section{Synaptophysin and other protein and mRNA levels in occipital cortex}

Five series in four studies (51 patients and 48 controls) measured synaptophysin protein levels in the occipital cortex. There were no significant differences in synaptophysin levels in schizophrenia patients when compared to healthy controls in the occipital cortex $(\mathrm{ES}=-0.16 ; z=-0.45 ; 95 \% \mathrm{CI}=-0.84$, $0.52 ; p=0.65$-Supplementary Figure 9). One study measured synaptophysin mRNA levels in the occipital cortex, and found a significant reduction. Two studies measured PSD-95 in occipital cortex in schizophrenia: one found a significant increase in its mRNA, and one found no change in PSD-95 protein levels. There were insufficient studies for meta-analysis of other synaptic protein or mRNA levels in this region.

\section{Discussion}

Our main findings are that protein levels of the synaptic marker synaptophysin are significantly decreased in schizophrenia in the hippocampus and cingulate cortex. We also found a decreased level of synaptophysin mRNA levels in the hippocampus $[59,106]$ (see Supplementary Table 1).

The frontal cortex also shows a significant reduction in synaptophysin protein levels. However, the ES is numerically smaller than for hippocampus and CC. Moreover, the sub-analysis restricted to the DLPFC was not significant, and the mRNA data for synaptophysin in the frontal cortex are inconsistent, with two studies suggesting a reduction, and two studies suggesting no change (Supplementary Table 1). Furthermore, the other protein levels in frontal cortex that we meta-analysed (SNAP-25, PSD-95, VAMP, and syntaxin) are not significantly reduced. Taken together, this suggests findings are less consistent in the frontal cortex than the findings in the hippocampus and CC. Among the potential contributors to these inconsistencies are age [108] and mode of death $[109,110]$. However, all of our studies matched the subjects for age at death, and our metaregressions for suicide as manner of death were all not significant, suggesting this is unlikely to be a major contributor to inconsistency. Other potential explanations for these inconsistencies could be differences in protein quantification methodology, variations in dissection protocols, and differences in the biological substrate due to the heterogeneity of the illness being studied, in addition to subregional variability (as suggested by lack of difference in the DLPFC); we discuss each of these sources of variation in the methodological section below; see also the review by McCullumsmith and colleagues for a further discussion of the factors that may influence postmortem findings [109]. We found no evidence of synaptic protein change in the temporal and occipital cortex. Our meta-analytic findings are summarised in Table 1. 
Table 1 Summary of our meta-analytic results

\begin{tabular}{|c|c|c|c|c|c|}
\hline Protein: area: & synaptophysin & SNAP-25 & PSD-95 & VAMP & syntaxin \\
\hline Hippocampus & $\downarrow-0.65$ & N/A & N/A & N/A & N/A \\
\hline Cingulate cortex & $\downarrow-0.54$ & N/A & N/A & N/A & N/A \\
\hline Frontal cortex & $\downarrow-0.36$ & $\leftrightarrow-0.18$ & $\leftrightarrow-0.34$ & $\leftrightarrow-0.26$ & $\leftrightarrow 0.16$ \\
\hline Temporal cortex & $\leftrightarrow-0.31$ & N/A & N/A & N/A & N/A \\
\hline Occipital cortex & $\leftrightarrow-0.16$ & N/A & N/A & N/A & N/A \\
\hline
\end{tabular}

The number is the effect size (Hedges' $g$ ) and " $\downarrow$ " indicates a significant reduction in schizophrenia, while " $\leftrightarrow$ " indicates no significant difference N/A not available

\section{Interpretation of findings}

Our findings of reductions in synaptophysin levels extend postmortem microscopy studies in schizophrenia that have found synaptic loss in the hippocampus [111, 112] and ACC [113] by providing meta-analytic evidence consistent with loss of synapses between neurons. They also extend a meta-analysis of genetic expression studies that found that genes in the presynaptic secretory function category (including synaptophysin) were significantly altered in schizophrenia [114], by providing evidence that this translates into alterations in protein levels of synaptophysin. Interestingly, the brain areas we found to have lower synaptophysin levels are among the regions that show the most volume loss in schizophrenia [115-120]. There is evidence that this cortical loss is at least partially due to reduced neuropil, including reduced synaptic compartments, rather than neuronal loss [121]. It is therefore possible that the reductions in the synaptic marker observed in our meta-analysis indicate that loss of synapses contributes to the brain volume loss seen in imaging and postmortem studies. Consistent with this, volume loss in hippocampus in schizophrenia is present from the onset of symptoms, predates antipsychotic exposure, and does not appear to be secondary to neuron loss [7, 18, 122-124], occurring in the absence of a change in total neuron numbers $[15,18]$. However, it should be recognised that there is considerable debate about the cellular changes that underlie brain volume alterations in schizophrenia, and other cellular changes, including alterations in axonal density, glial cells and neuronal size could also contribute to loss of neuropil [121]. The role of synaptic alterations and contribution of these other factors to volume loss needs further testing. Postmortem studies of the $\mathrm{CC}$ in schizophrenia have also found structural alterations, including synaptic loss [113, 125].

We found no significant changes in synaptic density in some of the brain areas studied in this meta-analysis, such as temporal and occipital cortices. Taken with our findings of significant reductions in hippocampus, cingulate and frontal cortex, this could suggest that synaptic loss shows regional specificity, affecting some areas more than others, which is similar to the pattern of regional volume changes in schizophrenia [10,120]. This is consistent with models of schizophrenia that implicate the hippocampus and frontal cortex as central to the pathophysiology of the disorder [5, $7,118,123,125-130]$. However, while the lack of significant differences in the temporal and occipital cortex raises the question of what underlies the grey matter volume reductions commonly reported in these regions [120, 131], we caution about over-interpretation of regional differences as there is a risk of a type II error. Recent work has also suggested a temporal specificity of synaptic change in schizophrenia, with synaptogenesis predominating earlier in the disease, and synaptic loss in chronic phases [132]. Ultimately, further studies are needed to compare subregions and timing with regards to disease onset.

Although there is some evidence that synaptophysin might be more abundant in glutamatergic than in GABAergic vesicles [133], it should be noted that it is not specific enough to particular synapses to draw firm conclusions. Thus, the reductions may reflect a global loss of synapses or be specific to particular neuronal populations.

Our findings of a significant reduction in frontal cortex in synaptophysin but not other synaptic markers is intriguing. Synaptophysin is specific to presynaptic nerve terminals $[29,30]$. It binds cholesterol, which is required for the genesis of synaptic vesicles [134]. This could indicate dysfunction in vesicle formation. Synaptophysin is considered one of the best proxies for synaptic density [27], and may be more sensitive to detecting synaptic reductions than the other markers, so the lack of reductions in the other markers could be a type II error. Ultimately, large studies comparing multiple synaptic marker levels across brain regions are required to definitively test whether there is greater reduction in some regions, such as the hippocampus, and proteins relative to other regions and proteins.

\section{Methodological considerations}

A potential limitation of this meta-analysis is that studies used different methods of protein quantification (24 studies used western blotting (WB), 7 immunohistochemistry and 5 
using ELISA-see Supplementary Information). However, a study comparing the different techniques for assessing synaptophysin levels in brain tissue found that WB and immunohistochemistry methods give similar results [27]. Another study compared WB and ELISA for synaptophysin quantification found that ELISA might be more robust at synaptophysin quantitation [135]. However, combining different methods with different levels of precision and sensitivity in the same meta-analysis should not account for our findings of reductions in schizophrenia, as the degree of precision is taken into account by the measure of dispersion, and variability in this would reduce the sensitivity to detect differences between groups, if it had any effect. Furthermore, we have used a random-effects model approach, which takes into account inter-study variability. However, we cannot exclude that our findings of no significant differences in the other regions examined could be a type II error due to variability in the sensitivity of methods used, and the smaller number of studies that assessed these areas, meaning that our meta-analysis may have been underpowered to detect small effects. Further studies are needed in these regions to rule this possibility out.

A potential confounder in the studies included is the use of antipsychotic medication in samples. There is evidence to suggest that antipsychotics may cause brain structural abnormalities, such as striatal [136] or brain volumetric changes [137]. However, studies have shown no difference in synaptophysin levels in the hippocampus of rats after antipsychotic exposure [59]; it should be noted that the animals used in these experiments were healthy animals, and could therefore not fully reflect results in schizophrenia. Similar studies on the frontal cortex and striatum have shown either no change or an increase in synaptophysin following antipsychotic treatment [138-140]. In addition, non-human primate studies have shown that synaptophysin levels are not affected following the continuous administration of haloperidol for several weeks [141, 142]. Thus, we find that antipsychotic treatment is unlikely to account for the reductions in synaptophysin, but studies in antipsychotic-naïve patients are required to definitively rule an effect out. Studying lifetime antipsychotic dose as a meta-regressor was not possible in the present study as this information was not present in the majority of studies. Unfortunately, it was also impossible to study illness duration as a meta-regressor as this information was not present in the majority of the included studies.

PMI was significantly different between groups in 5 out of 36 studies. When the one non-matched PMI study was removed from the analysis of synaptophysin in the frontal cortex, it did not affect the overall significance. However, in the analysis of synaptophysin in $\mathrm{CC}$, after removing the study that did not match groups for PMI [86], the overall effect was no longer significant, suggesting that differences in PMI may contribute to differences in this region.
We were able to explore the potential effect of suicide on our findings because it was widely reported, but this was not possible for other potential contributors to inconsistency because they were not consistently reported. This should not be taken as indicating they are not important, and it is recommended that future studies report these in more detail to facilitate comparisons.

Other potential sources of variability are the differences in laterality [143, 144], dissection protocols and tissue processing. However, few studies reported data by hemisphere, precluding analysis of potential differences. Tissues sources are summarised in the Supplementary Tables; unfortunately, few papers mention the dissection protocol that was used, therefore it was impossible for us to take this factor into account. In addition to this, the brains came from different sources: some samples came from brain banks, which collect samples from different consortia, each with different dissection protocols; some papers sourced their own samples without specifying the dissection technique they used, and for 17 samples the source was not mentioned.

There is evidence that there may be variability in gene expression depending on the specific dissection boundaries [145]. Some of the studies we included used immunohistochemistry to quantify synaptic proteins, and reported protein and mRNA levels for different tissue layers and/or very specific sub-regions within the same region, thus, also confirming that molecular profiles within brain regions vary on a gradient $[39,56,64,65,69,73,93,97,103]$. Other studies used tissue homogenates, therefore, in our metaanalysis, we combined the data from different sub-regions within a given region, which could obscure sub-regional differences, as suggested by analyses of grey matter alterations [144].

\section{Future directions}

Our findings raise a number of questions. In particular, whether the reduction in synaptophysin is developmental or develops later in life; whether it is primary or secondary to other factors and changes, such as oxidative stress [146] or inflammation [147, 148]; whether it indicates a loss of synapses or the loss of synaptophysin specifically, and how it relates to grey matter changes and symptoms. Further studies are needed to tackle these questions. The recent development of PET tracers that index synaptic proteins provides a means of addressing some of them. Longitudinal in-vivo imaging studies with synaptic tracers, from childhood to early in the course of illness to a chronic stage, are needed to address the questions relating to the time course of the changes. The concomitant study of other biological factors of the illness, such as oxidative stress, inflammation and structural brain changes, would allow the correlations of these elements with synaptic loss to be tested. This work 
would need to be complemented by preclinical studies to determine the effect of these potential mechanisms on synaptic proteins that can be measured postmortem and in vivo using PET imaging.

Finally, these results may also have implications for drug development. In animal models, the administration of a p21-activated kinases (PAK) inhibitor in late adolescence has been shown to block synaptic loss and prevent adult behavioural deficits associated with schizophrenia [149]. Reversing or preventing synaptic loss could therefore be a potential treatment target in schizophrenia.

\section{Conclusions}

There is a significant reduction in synaptophysin in the hippocampus, cingulate and frontal cortices of patients with schizophrenia as compared to matched healthy controls, although the findings in the $\mathrm{CC}$ were not significant after excluding a study that did not match for PMI, and we did not find significant results for the levels of SNAP-25, PSD95, VAMP and syntaxin in the frontal cortex. We found no difference in temporal cortex and occipital cortex for synaptophysin. These findings are consistent with models that implicate synaptic loss in hippocampus and frontal cortical regions in the pathophysiology of schizophrenia, but further studies are required to determine if this is a general loss of synapses or specific loss of synaptophysin, and to test regional variability.

Acknowledgements This study was funded by grant MC-A6565QD30 from the Medical Research Council, by grant 666 from the Maudsley Charity, by grant 094849/Z/10/Z from the Brain \& Behavior Research Foundation, by the Wellcome Trust (Professor Howes)

Funding: ODH conducts research funded by the Medical Research Council, the National Institute for Health Research, and the Maudsley Charity and received investigator-initiated research funding from or participation in advisory or speaker meetings organised by AstraZeneca, Bristol-Myers Squibb, Eli Lilly, Janssen, Lundbeck, LydenDelta, Servier, and Roche. TRM conducts research funded by the Medical Research Council, and received funding from participation in advisory or speaker meetings organised by Lundbeck, Pfizer and Janssen-Cilag.

\section{Compliance with ethical standards}

Conflict of interest The authors declare that they have no conflict of interest.

Open Access This article is licensed under a Creative Commons Attribution 4.0 International License, which permits use, sharing, adaptation, distribution and reproduction in any medium or format, as long as you give appropriate credit to the original author(s) and the source, provide a link to the Creative Commons license, and indicate if changes were made. The images or other third party material in this article are included in the article's Creative Commons license, unless indicated otherwise in a credit line to the material. If material is not included in the article's Creative Commons license and your intended use is not permitted by statutory regulation or exceeds the permitted use, you will need to obtain permission directly from the copyright holder. To view a copy of this license, visit http://creativecommons. org/licenses/by/4.0/.

\section{References}

1. Hafner H, an der Heiden W. Epidemiology of schizophrenia. Can J Psychiatry. 1997;42:139-51.

2. Howes OD, Murray RM. Schizophrenia: an integrated sociodevelopmental-cognitive model. Lancet. 2014;383: 1677-87.

3. Johnstone EC, Crow TJ, Frith CD, Husband J, Kreel L. Cerebral ventricular size and cognitive impairment in chronic schizophrenia. Lancet. 1976;2:924-6.

4. Van Horn JD, McManus IC. Ventricular enlargement in schizophrenia. A meta-analysis of studies of the ventricle:brain ratio (VBR). Br J Psychiatry. 1992;160:687-97.

5. Turetsky B, Cowell PE, Gur RC, Grossman RI, Shtasel DL, Gur RE. Frontal and temporal lobe brain volumes in schizophrenia: relationship to symptoms and clinical subtype. Arch General Psychiatry. 1995;52:1061-70.

6. Fornito A, Yücel M, Patti J, Wood S, Pantelis C. Mapping grey matter reductions in schizophrenia: an anatomical likelihood estimation analysis of voxel-based morphometry studies. Schizophr Res. 2009;108:104-13.

7. Heckers S, Konradi C. Hippocampal pathology in schizophrenia. Curr Top Behav Neurosci. 2010;4:529-53.

8. Velakoulis D, Pantelis C, McGorry PD, Dudgeon P, Brewer W, Cook M, et al. Hippocampal volume in first-episode psychoses and chronic schizophrenia: a high-resolution magnetic resonance imaging study. Arch Gen Psychiatry. 1999;56:133-41.

9. Nelson MD, Saykin AJ, Flashman LA, Riordan HJ. Hippocampal volume reduction in schizophrenia as assessed by magnetic resonance imaging: a meta-analytic study. Arch Gen Psychiatry. 1998;55:433-40.

10. Wright IC, Rabe-Hesketh S, Woodruff PW, David AS, Murray RM, Bullmore ET. Meta-analysis of regional brain volumes in schizophrenia. Am J Psychiatry. 2000;157:16-25.

11. Bloomfield PS, Selvaraj S, Veronese M, Rizzo G, Bertoldo A, Owen DR, et al. Microglial Activity in people at ultra high risk of psychosis and in schizophrenia: An [(11)C]PBR28 PET brain imaging study. Am J Psychiatry. 2016;173:44-52.

12. Van Berckel BN, Bossong MG, Boellaard R, Kloet R, Schuitemaker A, Caspers E, et al. Microglia activation in recent-onset schizophrenia: a quantitative (R)-[11 C] PK11195 positron emission tomography study. Biol Psychiatry. 2008;64:820-2.

13. Arnold SE, Trojanowski JQ, Gur RE, Blackwell P, Han LY, Choi C. Absence of neurodegeneration and neural injury in the cerebral cortex in a sample of elderly patients with schizophrenia. Arch Gen Psychiatry. 1998;55:225-32.

14. Pakkenberg B. Total nerve cell number in neocortex in chronic schizophrenics and controls estimated using optical disectors. Biol Psychiatry. 1993;34:768-72.

15. Walker MA, Highley JR, Esiri MM, McDonald B, Roberts HC, Evans SP, et al. Estimated neuronal populations and volumes of the hippocampus and its subfields in schizophrenia. Am J Psychiatry. 2002;159:821-8.

16. Baldessarini RJ, Hegarty JD, Bird ED, Benes FM. Meta-analysis of postmortem studies of Alzheimer's disease-like neuropathology in schizophrenia. Am J Psychiatry. 1997;154:861-3.

17. Thune JJ, Uylings HB, Pakkenberg B. No deficit in total number of neurons in the prefrontal cortex in schizophrenics. J Psychiatr Res. 2001;35:15-21. 
18. Heckers S, Heinsen H, Geiger B, Beckmann H. Hippocampal neuron number in schizophrenia: a stereological study. Arch General Psychiatry. 1991;48:1002-8.

19. Feinberg I. Schizophrenia: caused by a fault in programmed synaptic elimination during adolescence? J Psychiatr Res. 1982;17:319-34.

20. Weinberger DR. Implications of normal brain development for the pathogenesis of schizophrenia. Arch Gen Psychiatry. 1987;44:660-9.

21. Murray RM, Lewis SW. Is schizophrenia a neurodevelopmental disorder? Br Med J (Clin ResEd). 1987;295:681-2.

22. Lewis DA, Levitt P. Schizophrenia as a disorder of neurodevelopment. Annu Rev Neurosci. 2002;25:409-32.

23. Eastwood SL, Burnet PW, McDonald B, Clinton J, Harrison PJ. Synaptophysin gene expression in human brain: a quantitative in situ hybridization and immunocytochemical study. Neuroscience. 1994;59:881-92.

24. Masliah E, Terry RD, Alford M, DeTeresa R. Quantitative immunohistochemistry of synaptophysin in human neocortex: an alternative method to estimate density of presynaptic terminals in paraffin sections. J Histochem Cytochem. 1990;38:837-44.

25. Masliah E, Terry RD, DeTeresa RM, Hansen LA. Immunohistochemical quantification of the synapse-related protein synaptophysin in Alzheimer disease. Neurosci Lett. 1989;103:234-9.

26. Walaas SI, Jahn R, Greengard P. Quantitation of nerve terminal populations: synaptic vesicle-associated proteins as markers for synaptic density in the rat neostriatum. Synapse. 1988;2:516-20.

27. Calhoun ME, Jucker M, Martin LJ, Thinakaran G, Price DL, Mouton PR. Comparative evaluation of synaptophysin-based methods for quantification of synapses. J Neurocytol. 1996;25:821-8.

28. Becher A, Drenckhahn A, Pahner I, Margittai M, Jahn R, Ahnert-Hilger G. The synaptophysin-synaptobrevin complex: a hallmark of synaptic vesicle maturation. J Neurosci. 1999;19: 1922-31.

29. Fletcher TL, Cameron P, De Camilli P, Banker G. The distribution of synapsin I and synaptophysin in hippocampal neurons developing in culture. J Neurosci. 1991;11:1617-26.

30. Navone F, Jahn R, Di Gioia G, Stukenbrok H, Greengard P, De Camilli P. Proteinp38: an integral membrane protein specific for small vesicles of neurons and neuroendocrine cells. J Cell Biol. 1986;103(6 Pt 1):2511-27.

31. Raber J, Mehta PP, Kreifeldt M, Parsons LH, Weiss F, Bloom $\mathrm{FE}$, et al. Coloboma hyperactive mutant mice exhibit regional and transmitter-specific deficits in neurotransmission. J Neurochem. 1997;68:176-86.

32. Cheng J, Xiong Z, Duffney LJ, Wei J, Liu A, Liu S, et al. Methylphenidate exerts dose-dependent effects on glutamate receptors and behaviors. Biol Psychiatry. 2014;76:953-62.

33. Selvaraj S, Arnone D, Cappai A, Howes O. Alterations in the serotonin system in schizophrenia: a systematic review and metaanalysis of postmortem and molecular imaging studies. Neurosci Biobehav Rev. 2014;45:233-45.

34. Howes OD, McCutcheon R, Owen MJ, Murray RM. The role of genes, stress, and dopamine in the development of schizophrenia. Biol Psychiatry. 2017;81:9-20.

35. Looney MR, Dohan FC Jr., Davies KG, Seidenberg M, Hermann BP, Schweitzer JB. Synaptophysin immunoreactivity in temporal lobe epilepsy-associated hippocampal sclerosis. Acta Neuropathol. 1999;98:179-85.

36. Sinclair LI, Tayler HM, Love S. Synaptic protein levels altered in vascular dementia. Neuropathol Appl Neurobiol. 2015;41: 533-43.

37. Sze CI, Bi H, Kleinschmidt-DeMasters BK, Filley CM, Martin LJ. Selective regional loss of exocytotic presynaptic vesicle proteins in Alzheimer's disease brains. J Neurol Sci. 2000;175: 81-90.

38. Brose N. For better or for worse: complexins regulate SNARE function and vesicle fusion. Traffic. 2008;9:1403-13.

39. Eastwood S, Harrison P. Hippocampal synaptic pathology in schizophrenia, bipolar disorder and major depression: a study of complexin mRNAs. Mol Psychiatry. 2000;5:425.

40. Ferreira A, Rapoport M. The synapsins: beyond the regulation of neurotransmitter release. Cell Mol Life Sci. 2002;59:589-95.

41. Porton B, Wetsel WC, Kao HT. Synapsin III: role in neuronal plasticity and disease. Semin Cell Dev Biol. 2011;22:416-24.

42. Geppert M, Goda Y, Stevens CF, Sudhof TC. The small GTPbinding protein Rab3A regulates a late step in synaptic vesicle fusion. Nature. 1997;387:810.

43. Ok-Ho S, Rizo J, Südhof TC. Synaptotagmin function in dense core vesicle exocytosis studied in cracked PC12 cells. Nat Neurosci. 2002;5:649.

44. El-Husseini AE-D, Schnell E, Chetkovich DM, Nicoll RA, Bredt DS. PSD-95 involvement in maturation of excitatory synapses. Science. 2000;290:1364-8.

45. Béique J-C, Lin D-T, Kang M-G, Aizawa H, Takamiya K, Huganir RL. Synapse-specific regulation of AMPA receptor function by PSD-95. Proc Natl Acad Sci. 2006;103:19535-40.

46. Bhattacharyya S, Biou V, Xu W, Schlüter O, Malenka RC. A critical role for PSD-95/AKAP interactions in endocytosis of synaptic AMPA receptors. Nat Neurosci. 2009;12:172-81.

47. Jackson D, Turner R. Power analysis for random-effects metaanalysis. Res Synth Methods. 2017;8:290-302.

48. Funk AJ, Mielnik CA, Koene R, Newburn E, Ramsey AJ, Lipska BK, et al. Postsynaptic density-95 isoform abnormalities in schizophrenia. Schizophr Bull. 2017;43:891-9.

49. Albert KA, Hemmings HC Jr., Adamo AI, Potkin SG, Akbarian S, Sandman CA, et al. Evidence for decreased DARPP-32 in the prefrontal cortex of patients with schizophrenia. Arch Gen Psychiatry. 2002;59:705-12.

50. Barksdale KA, Lahti AC, Roberts RC. Synaptic proteins in the postmortem anterior cingulate cortex in schizophrenia: relationship to treatment and treatment response. Neuropsychopharmacology. 2014;39:2095-103.

51. Beasley CL, Honer WG, Bergmann K, Falkai P, Lutjohann D, Bayer TA. Reductions in cholesterol and synaptic markers in association cortex in mood disorders. Bipolar Disord. 2005;7:449-55.

52. Blennow K, Bogdanovic N, Heilig M, Grenfeldt B, Karlsson I, Davidsson P. Reduction of the synaptic protein rab3a in the thalamus and connecting brain regions in post-mortem schizophrenic brains. J Neural Transm. 2000;107:1085-97.

53. Browning MD, Dudek EM, Rapier JL, Leonard S, Freedman R. Significant reductions in synapsin but not synaptophysin specific activity in the brains of some schizophrenics. Biol Psychiatry. 1993;34:529-35.

54. Castillo MA, Ghose S, Tamminga CA, Ulery-Reynolds PG. Deficits in syntaxin 1 phosphorylation in schizophrenia prefrontal cortex. Biol Psychiatry. 2010;67:208-16.

55. Catts VS, Derminio DS, Hahn CG, Weickert CS. Postsynaptic density levels of the NMDA receptor NR1 subunit and PSD-95 protein in prefrontal cortex from people with schizophrenia. NPJ Schizophr. 2015;1:15037.

56. Chambers JS, Thomas D, Saland L, Neve RL, Perrone-Bizzozero NI. Growth-associated protein 43 (GAP-43) and synaptophysin alterations in the dentate gyrus of patients with schizophrenia. Prog Neuropsychopharmacol Biol Psychiatry. 2005;29:283-90.

57. Davidsson P, Gottfries J, Bogdanovic N, Ekman R, Karlsson I, Gottfries CG, et al. The synaptic-vesicle-specific proteins rab3a and synaptophysin are reduced in thalamus and related cortical 
brain regions in schizophrenic brains. Schizophr Res. 1999;40: 23-9.

58. Dracheva S, Marras SA, Elhakem SL, Kramer FR, Davis KL, Haroutunian V. N-methyl-D-aspartic acid receptor expression in the dorsolateral prefrontal cortex of elderly patients with schizophrenia. Am J Psychiatry. 2001;158:1400-10.

59. Eastwood SL, Burnet PW, Harrison PJ. Altered synaptophysin expression as a marker of synaptic pathology in schizophrenia. Neuroscience. 1995;66:309-19.

60. Eastwood SL, Cairns NJ, Harrison PJ. Synaptophysin gene expression in schizophrenia. Investig Synaptic Pathol Cereb cortex Br J Psychiatry. 2000;176:236-42.

61. Eastwood SL, Harrison PJ. Decreased synaptophysin in the medial temporal lobe in schizophrenia demonstrated using immunoautoradiography. Neuroscience. 1995;69:339-43.

62. Eastwood SL, Harrison PJ. Hippocampal synaptic pathology in schizophrenia, bipolar disorder and major depression: a study of complexin mRNAs. Mol Psychiatry. 2000;5:425-32.

63. Eastwood SL, Harrison PJ. Synaptic pathology in the anterior cingulate cortex in schizophrenia and mood disorders. A review and a Western blot study of synaptophysin, GAP-43 and the complexins. Brain Res Bull. 2001;55:569-78.

64. Eastwood SL, Harrison PJ. Decreased expression of vesicular glutamate transporter 1 and complexin II mRNAs in schizophrenia: further evidence for a synaptic pathology affecting glutamate neurons. Schizophr Res. 2005;73:159-72.

65. Fatemi SH, Earle JA, Stary JM, Lee S, Sedgewick J. Altered levels of the synaptosomal associated protein SNAP-25 in hippocampus of subjects with mood disorders and schizophrenia. Neuroreport. 2001;12:3257-62.

66. Focking M, Lopez LM, English JA, Dicker P, Wolff A, Brindley E, et al. Proteomic and genomic evidence implicates the postsynaptic density in schizophrenia. Mol Psychiatry. 2015;20: 424-32.

67. Fung SJ, Sivagnanasundaram S, Weickert CS. Lack of change in markers of presynaptic terminal abundance alongside subtle reductions in markers of presynaptic terminal plasticity in prefrontal cortex of schizophrenia patients. Biol Psychiatry. 2011;69:71-9.

68. Funk AJ, McCullumsmith RE, Haroutunian V, MeadorWoodruff JH. Abnormal activity of the MAPK- and cAMPassociated signaling pathways in frontal cortical areas in postmortem brain in schizophrenia. Neuropsychopharmacol. 2012;37:896-905.

69. Gilabert-Juan J, Varea E, Guirado R, Blasco-Ibanez JM, Crespo C, Nacher J. Alterations in the expression of PSA-NCAM and synaptic proteins in the dorsolateral prefrontal cortex of psychiatric disorder patients. Neurosci Lett. 2012;530:97-102.

70. Gil-Pisa I, Munarriz-Cuezva E, Ramos-Miguel A, Uriguen L, Meana JJ, Garcia-Sevilla JA. Regulation of munc18-1 and syntaxin-1A interactive partners in schizophrenia prefrontal cortex: down-regulation of munc18-1a isoform and $75 \mathrm{kDa}$ SNARE complex after antipsychotic treatment. Int $\mathrm{J}$ Neuropsychopharmacol. 2012;15:573-88.

71. Glantz LA, Austin MC, Lewis DA. Normal cellular levels of synaptophysin mRNA expression in the prefrontal cortex of subjects with schizophrenia. Biol Psychiatry. 2000;48:389-97.

72. Glantz LA, Gilmore JH, Overstreet DH, Salimi K, Lieberman JA, Jarskog LF. Pro-apoptotic Par-4 and dopamine D2 receptor in temporal cortex in schizophrenia, bipolar disorder and major depression. Schizophr Res. 2010;118:292-9.

73. Glantz LA, Lewis DA. Reduction of synaptophysin immunoreactivity in the prefrontal cortex of subjects with schizophrenia. Reg Diagn Specif Arch Gen Psychiatry. 1997;54:660-9.
74. Gray LJ, Dean B, Kronsbein HC, Robinson PJ, Scarr E. Region and diagnosis-specific changes in synaptic proteins in schizophrenia and bipolar I disorder. Psychiatry Res. 2010;178:374-80.

75. Hahn CG, Wang HY, Cho DS, Talbot K, Gur RE, Berrettini $\mathrm{WH}$, et al. Altered neuregulin 1-erbB4 signaling contributes to NMDA receptor hypofunction in schizophrenia. Nat Med. 2006;12:824-8.

76. Halim ND, Weickert CS, McClintock BW, Hyde TM, Weinberger DR, Kleinman JE, et al. Presynaptic proteins in the prefrontal cortex of patients with schizophrenia and rats with abnormal prefrontal development. Mol Psychiatry. 2003;8: 797-810.

77. Harrison PJ, Eastwood SL. Preferential involvement of excitatory neurons in medial temporal lobe in schizophrenia. Lancet. 1998;352:1669-73.

78. Honer WG, Falkai P, Bayer TA, Xie J, Hu L, Li HY, et al. Abnormalities of SNARE mechanism proteins in anterior frontal cortex in severe mental illness. Cereb Cortex. 2002;12:349-56.

79. Honer WG, Falkai P, Chen C, Arango V, Mann JJ, Dwork AJ. Synaptic and plasticity-associated proteins in anterior frontal cortex in severe mental illness. Neuroscience. 1999;91:1247-55.

80. Honer WG, Falkai P, Young C, Wang T, Xie J, Bonner J, et al. Cingulate cortex synaptic terminal proteins and neural cell adhesion molecule in schizophrenia. Neuroscience. 1997;78: 99-110.

81. Ide M, Lewis DA. Altered cortical CDC42 signaling pathways in schizophrenia: implications for dendritic spine deficits. Biol Psychiatry. 2010;68:25-32.

82. Imai C, Sugai T, Iritani S, Niizato K, Nakamura R, Makifuchi T, et al. A quantitative study on the expression of synapsin II and $\mathrm{N}$-ethylmaleimide-sensitive fusion protein in schizophrenic patients. Neurosci Lett. 2001;305:185-8.

83. Karson CN, Mrak RE, Schluterman KO, Sturner WQ, Sheng JG, Griffin WS. Alterations in synaptic proteins and their encoding mRNAs in prefrontal cortex in schizophrenia: a possible neurochemical basis for 'hypofrontality'. Mol Psychiatry. 1999;4: 39-45.

84. Kristiansen LV, Beneyto M, Haroutunian V, Meador-Woodruff $\mathrm{JH}$. Changes in NMDA receptor subunits and interacting PSD proteins in dorsolateral prefrontal and anterior cingulate cortex indicate abnormal regional expression in schizophrenia. Mol Psychiatry. 2006;11:737-47.

85. Landen M, Davidsson P, Gottfries CG, Grenfeldt B, Stridsberg $\mathrm{M}$, Blennow K. Reduction of the small synaptic vesicle protein synaptophysin but not the large dense core chromogranins in the left thalamus of subjects with schizophrenia. Biol Psychiatry. 1999;46:1698-702.

86. Landen M, Davidsson P, Gottfries CG, Mansson JE, Blennow K. Reduction of the synaptophysin level but normal levels of glycerophospholipids in the gyrus cinguli in schizophrenia. Schizophr Res. 2002;55:83-8.

87. Matosin N, Fernandez-Enright F, Lum JS, Engel M, Andrews JL, Gassen NC, et al. Molecular evidence of synaptic pathology in the CA1 region in schizophrenia. NPJ Schizophr. 2016;2: 16022.

88. Nowakowski C, Kaufmann WA, Adlassnig C, Maier H, Salimi $\mathrm{K}$, Jellinger KA, et al. Reduction of chromogranin B-like immunoreactivity in distinct subregions of the hippocampus from individuals with schizophrenia. Schizophr Res. 2002;58: 43-53.

89. Perrone-Bizzozero NI, Sower AC, Bird ED, Benowitz LI, Ivins KJ, Neve RL. Levels of the growth-associated protein GAP-43 are selectively increased in association cortices in schizophrenia. Proc Natl Acad Sci USA. 1996;93:14182-7. 
90. Porton B, Wetsel WC. Reduction of synapsin III in the prefrontal cortex of individuals with schizophrenia. Schizophr Res. 2007;94:366-70.

91. Ramos-Miguel A, Beasley CL, Dwork AJ, Mann JJ, Rosoklija G, Barr AM, et al. Increased SNARE protein-protein interactions in orbitofrontal and anterior cingulate cortices in schizophrenia. Biol Psychiatry. 2015;78:361-73.

92. Rao JS, Kim HW, Harry GJ, Rapoport SI, Reese EA. Increased neuroinflammatory and arachidonic acid cascade markers, and reduced synaptic proteins, in the postmortem frontal cortex from schizophrenia patients. Schizophr Res. 2013;147:24-31.

93. Sawada K, Barr AM, Nakamura M, Arima K, Young CE, Dwork AJ, et al. Hippocampal complexin proteins and cognitive dysfunction in schizophrenia. Arch Gen Psychiatry. 2005;62: 263-72.

94. Sawada K, Young CE, Barr AM, Longworth K, Takahashi S, Arango V, et al. Altered immunoreactivity of complexin protein in prefrontal cortex in severe mental illness. Mol Psychiatry. 2002; 7:484-92.

95. Scarr E, Gray L, Keriakous D, Robinson PJ, Dean B. Increased levels of SNAP-25 and synaptophysin in the dorsolateral prefrontal cortex in bipolar I disorder. Bipolar Disord. 2006;8: 133-43.

96. Sokolov BP, Tcherepanov AA, Haroutunian V, Davis KL. Levels of mRNAs encoding synaptic vesicle and synaptic plasma membrane proteins in the temporal cortex of elderly schizophrenic patients. Biol Psychiatry. 2000;48:184-96.

97. Talbot K, Eidem WL, Tinsley CL, Benson MA, Thompson EW, Smith RJ, et al. Dysbindin-1 is reduced in intrinsic, glutamatergic terminals of the hippocampal formation in schizophrenia. $\mathrm{J}$ Clin Invest. 2004;113:1353-63.

98. Tan ML, Dyck BA, Gabriele J, Daya RP, Thomas N, Sookram $\mathrm{C}$, et al. Synapsin II gene expression in the dorsolateral prefrontal cortex of brain specimens from patients with schizophrenia and bipolar disorder: effect of lifetime intake of antipsychotic drugs. Pharm J. 2014;14:63-9.

99. Tcherepanov AA, Sokolov BP. Age-related abnormalities in expression of mRNAs encoding synapsin $1 \mathrm{~A}$, synapsin $1 \mathrm{~B}$, and synaptophysin in the temporal cortex of schizophrenics. J Neurosci Res. 1997;49:639-44.

100. Thompson PM, Cruz DA, Fucich EA, Olukotun DY, Takahashi M, Itakura M. SNAP-25a/b isoform levels in human brain dorsolateral prefrontal cortex and anterior cingulate cortex. Mol Neuropsychiatry. 2015;1:220-34.

101. Thompson PM, Egbufoama S, Vawter MP. SNAP-25 reduction in the hippocampus of patients with schizophrenia. Prog Neuropsychopharmacol Biol Psychiatry. 2003;27:411-7.

102. Thompson PM, Sower AC, Perrone-Bizzozero NI. Altered levels of the synaptosomal associated protein SNAP-25 in schizophrenia. Biol Psychiatry. 1998;43:239-43.

103. Toro C, Deakin JF. NMDA receptor subunit NRI and postsynaptic protein PSD-95 in hippocampus and orbitofrontal cortex in schizophrenia and mood disorder. Schizophr Res. 2005;80:323-30.

104. Toyooka K, Iritani S, Makifuchi T, Shirakawa O, Kitamura N, Maeda K, et al. Selective reduction of a PDZ protein, SAP-97, in the prefrontal cortex of patients with chronic schizophrenia. J Neurochem. 2002;83:797-806.

105. Vawter MP, Thatcher L, Usen N, Hyde TM, Kleinman JE, Freed WJ. Reduction of synapsin in the hippocampus of patients with bipolar disorder and schizophrenia. Mol Psychiatry. 2002;7: $571-8$.

106. Webster MJ, Shannon Weickert C, Herman MM, Hyde TM, Kleinman JE. Synaptophysin and GAP-43 mRNA levels in the hippocampus of subjects with schizophrenia. Schizophr Res. 2001;49:89-98.
107. Young CE, Arima K, Xie J, Hu L, Beach TG, Falkai P, et al. SNAP-25 deficit and hippocampal connectivity in schizophrenia. Cereb Cortex. 1998;8:261-8.

108. Hatanpää K, Isaacs KR, Shirao T, Brady DR, Rapoport SI. Loss of proteins regulating synaptic plasticity in normal aging of the human brain and in Alzheimer disease. J Neuropathol Exp Neurol. 1999;58:637-43.

109. McCullumsmith RE, Hammond JH, Shan D, Meador-Woodruff JH. Postmortem brain: an underutilized substrate for studying severe mental illness. Neuropsychopharmacology. 2014;39:65-87.

110. Dwivedi Y, Mondal AC, Rizavi HS, Conley RR. Suicide brain is associated with decreased expression of neurotrophins. Biol Psychiatry. 2005;58:315-24.

111. Kolomeets NS, Orlovskaya DD, Uranova NA. Decreased numerical density of CA3 hippocampal mossy fiber synapses in schizophrenia. Synapse. 2007;61:615-21.

112. Kolomeets NS, Orlovskaya DD, Rachmanova VI, Uranova NA. Ultrastructural alterations in hippocampal mossy fiber synapses in schizophrenia: a postmortem morphometric study. Synapse. 2005;57:47-55.

113. Fornito A, Yücel M, Dean B, Wood SJ, Pantelis C. Anatomical abnormalities of the anterior cingulate cortex in schizophrenia: bridging the gap between neuroimaging and neuropathology. Schizophr Bull. 2009;35:973-93.

114. Mirnics K, Middleton FA, Lewis DA, Levitt P. Analysis of complex brain disorders with gene expression microarrays: schizophrenia as a disease of the synapse. Trends Neurosci. 2001;24:479-86.

115. Honea R, Crow TJ, Passingham D, Mackay CE. Regional deficits in brain volume in schizophrenia: a meta-analysis of voxelbased morphometry studies. Am J Psychiatry. 2005;162: 2233-45.

116. Velakoulis D, Stuart GW, Wood SJ, Smith DJ, Brewer WJ, Desmond $\mathrm{P}$, et al. Selective bilateral hippocampal volume loss in chronic schizophrenia. Biol Psychiatry. 2001;50:531-9.

117. Steen RG, Mull C, Mcclure R, Hamer RM, Lieberman JA. Brain volume in first-episode schizophrenia. Br J Psychiatry. 2006;188: 510-8.

118. Borgwardt SJ, McGuire PK, Aston J, Gschwandtner U, Pflüger MO, Stieglitz R-D, et al. Reductions in frontal, temporal and parietal volume associated with the onset of psychosis. Schizophr Res. 2008;106:108-14.

119. Mitelman SA, Shihabuddin L, Brickman AM, Hazlett EA, Buchsbaum MS. Volume of the cingulate and outcome in schizophrenia. Schizophr Res. 2005;72:91-108.

120. Brugger SP, Howes OD. Heterogeneity and homogeneity of regional brain structure in schizophrenia: a meta-analysis. JAMA Psychiatry. 2017;74:1104-11.

121. Harrison PJ. The neuropathology of schizophrenia: a critical review of the data and their interpretation. Brain. 1999;122: 593-624.

122. Antonova E, Sharma T, Morris R, Kumari V. The relationship between brain structure and neurocognition in schizophrenia: a selective review. Schizophr Res. 2004;70:117-45.

123. Harrison PJ. The hippocampus in schizophrenia: a review of the neuropathological evidence and its pathophysiological implications. Psychopharmacol. 2004;174:151-62.

124. Ebdrup BH, Langkilde AR, Paulson OB. Hippocampal and caudate volume reductions in antipsychotic-naive first-episode schizophrenia. J Psychiatry Neurosci. 2010;35:95.

125. Benes FM, McSparren J, Bird ED, SanGiovanni JP, Vincent SL. Deficits in small interneurons in prefrontal and cingulate cortices of schizophrenic and schizoaffective patients. Arch Gen Psychiatry. 1991;48:996-1001.

126. Stone JM, Howes OD, Egerton A, Kambeitz J, Allen P, Lythgoe DJ, et al. Altered relationship between hippocampal glutamate 
levels and striatal dopamine function in subjects at ultra high risk of psychosis. Biol Psychiatry. 2010;68:599-602.

127. Lewis DA, Hashimoto T, Volk DW. Cortical inhibitory neurons and schizophrenia. Nat Rev Neurosci. 2005;6:312-24.

128. Broadbelt K, Byne W, Jones LB. Evidence for a decrease in basilar dendrites of pyramidal cells in schizophrenic medial prefrontal cortex. Schizophr Res. 2002;58:75-81.

129. Glahn DC, Ragland JD, Abramoff A, Barrett J, Laird AR, Bearden CE, et al. Beyond hypofrontality: a quantitative metaanalysis of functional neuroimaging studies of working memory in schizophrenia. Hum Brain Mapp. 2005;25:60-9.

130. Lewis DA. GABAergic local circuit neurons and prefrontal cortical dysfunction in schizophrenia. Brain Res Rev. 2000;31: $270-6$.

131. Ellison-Wright I, Bullmore E. Anatomy of bipolar disorder and schizophrenia: a meta-analysis. Schizophr Res. 2010;117:1-12.

132. Krystal JH, Anticevic A, Yang GJ, Dragoi G, Driesen NR, Wang $\mathrm{X}-\mathrm{J}$, et al. Impaired tuning of neural ensembles and the pathophysiology of schizophrenia: A translational and computational neuroscience perspective. Biol Psychiatry. 2017;81:874-85.

133. Grønborg M, Pavlos NJ, Brunk I, Chua JJ, Münster-Wandowski A, Riedel D, et al. Quantitative comparison of glutamatergic and GABAergic synaptic vesicles unveils selectivity for few proteins including MAL2, a novel synaptic vesicle protein. J Neurosci. 2010;30:2-12.

134. Thiele C, Hannah MJ, Fahrenholz F, Huttner WB. Cholesterol binds to synaptophysin and is required for biogenesis of synaptic vesicles. Nat Cell Biol. 2000;2:42-9.

135. Gottschall PE, Ajmo JM, Eakin AK, Howell MD, Mehta H, Bailey LA. Panel of synaptic protein ELISAs for evaluating neurological phenotype. Exp Brain Res. 2010;201:885-93.

136. Keshavan MS, Bagwell WW, Haas GL, Sweeney JA, Schooler NR, Pettegrew JW. Changes in caudate volume with neuroleptic treatment. Lancet. 1994;344:1434.

137. Madsen AL, Keidling N, Karle A, Esbjerg S, Hemmingsen R. Neuroleptics in progressive structural brain abnormalities in psychiatric illness. Lancet. 1998;352:784-5.
138. Eastwood SL, Burnet PW, Harrison PJ. Striatal synaptophysin expression and haloperidol-induced synaptic plasticity. Neuroreport. 1994;5:677-80.

139. Marin C, Tolosa E. Striatal synaptophysin levels are not indicative of dopaminergic supersensitivity. Neuropharmacology. 1997;36:1115-7.

140. Kessas M, Creed M, Nobrega JN. An examination of synaptic proteins following chronic haloperidol in a rat model of tardive dyskinesia. Psychol Neurosci. 2010;3:229.

141. Lidow MS, Song ZM, Castner SA, Allen PB, Greengard P, Goldman-Rakic PS. Antipsychotic treatment induces alterations in dendrite- and spine-associated proteins in dopamine-rich areas of the primate cerebral cortex. Biol Psychiatry. 2001;49:1-12.

142. Sweet RA, Henteleff RA, Zhang W, Sampson AR, Lewis DA. Reduced dendritic spine density in auditory cortex of subjects with schizophrenia. Neuropsychopharmacology. 2009;34: 374-89.

143. Bruder GE. Cerebral laterality and psychopathology: a review of dichotic listening studies. Schizophr Bull. 1983;9:134.

144. Vita A, De Peri L, Deste G, Sacchetti E. Progressive loss of cortical gray matter in schizophrenia: a meta-analysis and metaregression of longitudinal MRI studies. Transl Psychiatry. 2012;2:e190.

145. Fanselow MS, Dong H-W. Are the dorsal and ventral hippocampus functionally distinct structures? Neuron. 2010;65:7-19.

146. Do KQ, Cabungcal JH, Frank A, Steullet P, Cuenod M. Redox dysregulation, neurodevelopment, and schizophrenia. Curr Opin Neurobiol. 2009;19:220-30.

147. Howes O, McCutcheon R. Inflammation and the neural diathesis-stress hypothesis of schizophrenia: a reconceptualization. Transl Psychiatry. 2017;7:e1024.

148. Sawa A, Snyder SH. Schizophrenia: diverse approaches to a complex disease. Science. 2002;296:692-5.

149. Hayashi-Takagi A, Araki Y, Nakamura M, Vollrath B, Duron SG, Yan Z, et al. PAKs inhibitors ameliorate schizophreniaassociated dendritic spine deterioration in vitro and in vivo during late adolescence. Proc Natl Acad Sci. 2014;111:6461-6. 